EPJ Web of Conferences 12, 02003 (2011)

DOI: $10.1051 /$ epjconf/20111202003

(C) Owned by the authors, published by EDP Sciences, 2011

\title{
Experimental studies of the effect of irradiation on the anaerobic corrosion of carbon steel in relation to the Belgian supercontainer concept
}

\author{
N.R. Smart ${ }^{1, a}$ P.A.H. Fennell ${ }^{1}$, A.P. Rance ${ }^{1}$, R.J. Winsley ${ }^{1}$, B. Reddy ${ }^{1}$ \\ and B. Kursten ${ }^{1}$ \\ ${ }^{1}$ Serco Technical Consulting Services, Culham Science Centre, Abingdon, Oxfordshire \\ OX14 3DB, UK \\ ${ }^{2}$ SCK-CEN, Boeretang 200, $2400 \mathrm{Mol}$, Belgium
}

\begin{abstract}
This paper describes recent results from an investigation of the effects of $\gamma$-radiation on the anaerobic corrosion of carbon steel in cement, in relation to the Belgian Supercontainer Concept for radioactive waste disposal. Anaerobic corrosion rates were measured by monitoring hydrogen evolution and the corresponding electrochemical behaviour was investigated by measuring open circuit potential and linear polarisation resistance. The test medium was alkaline simulated porewater, at $\gamma$-irradiation dose rates of 0 and $25 \mathrm{~Gy} \mathrm{hr}^{-1}$, temperatures of $25^{\circ} \mathrm{C}$ and $80^{\circ} \mathrm{C}$ and chloride concentrations of 0 and $100 \mathrm{mg} / \mathrm{l}$. The effects of radiation on the corrosion behaviour were found to be small.
\end{abstract}

\section{INTRODUCTION}

The reference design for the Belgium Supercontainer for disposal of high-level nuclear waste and spent fuel consists of a $30 \mathrm{~mm}$ thick carbon steel cylindrical vessel ('the overpack') surrounding 309 grade stainless steel waste canisters. The overpack will be surrounded by a cementitious buffer material, which may or may not be encased in a stainless steel vessel ('the envelope'). This paper is concerned with the anaerobic corrosion processes that may affect the carbon steel overpack within the Supercontainer. The carbon steel will be exposed to alkaline porewater in the cementitious buffer or in the alkaline material which may be used as a filler in the annulus between the cementitious buffer and the overpack. After a relatively short period the interface between the steel and alkaline porewater will become anoxic as residual oxygen in the repository is consumed by aerobic corrosion and microbial activity. Low concentrations of chloride (typically $100 \mathrm{ppm}$ ) from the groundwater may penetrate the buffer and reach the surface of the overpack.

Following a review of the corrosion issues affecting the Supercontainer design an experimental programme was initiated to investigate (i) the possible effect of gamma radiation on the anaerobic corrosion rate of carbon steel in cementitious porewaters and on the nature of the corrosion products formed, and (ii) the effect of radiation on the electrochemical and corrosion behaviour of carbon steel corroding anaerobically in simulated concrete porewater conditions. Previous publications have reported earlier results from this programme $[1,2]$ for both gas generation and electrochemical measurements. The aim of this paper is to provide an update on this work programme, with the main focus being on the results of the electrochemical measurements, although the results from the gas generation experiments are also shown for comparison. In essence the work programme involved setting up test cells containing representative corrosion systems and exposing them to controlled gamma radiation

\footnotetext{
a e-mail: nick.smart@serco.com
}

This is an Open Access article distributed under the terms of the Creative Commons Attribution-Noncommercial License 3.0, which permits unrestricted use, distribution, and reproduction in any noncommercial medium, provided the original work is properly cited. 


\section{EPJ Web of Conferences}

fields, whilst continuously monitoring them. The programme was based on experimental experience gained by carrying out investigations of the anaerobic corrosion of steel in other waste disposal systems [3-5] including a limited number of corrosion experiments under gamma-irradiation [6].

The anaerobic corrosion of iron releases hydrogen by the following overall reaction:

$$
\mathrm{Fe}+2 \mathrm{H}_{2} \mathrm{O} \rightarrow \mathrm{Fe}(\mathrm{OH})_{2}+\mathrm{H}_{2} \mathrm{O}
$$

or, if the Schikorr reaction [7] occurs, by the reaction:

$$
3 \mathrm{Fe}+4 \mathrm{H}_{2} \mathrm{O} \rightarrow \mathrm{Fe}_{3} \mathrm{O}_{4}+4 \mathrm{H}_{2} \mathrm{O}
$$

Consequently, it is possible to monitor the progress of the iron anaerobic corrosion reaction by measuring the rate of hydrogen production.

\section{EXPERIMENTAL}

The experimental programme consisted of two parallel sets of measurements, firstly to monitor the rate of gas generation due to the anaerobic corrosion of carbon steel in alkaline conditions and secondly to monitor the electrochemical behaviour of carbon steel in simulated cementitious conditions, under both unirradiated and irradiated conditions. Gas generation rates and hence corrosion rates were measured using glass gas cells. Electrochemical behaviour was studied using sealed glass cells. Some experiments were carried out using sealed metal autoclaves, for both gas generation rate and electrochemical measurements, but these results will be reported in detail at a later date.

\subsection{Dose rate and temperature}

In the Supercontainer concept the dose rates of interest are $0.6 \mathrm{~Gy} \mathrm{hr}^{-1}$ (the average dose in the cement buffer) and 23-25 Gy hr${ }^{-1}$ (the dose rate at the surface of the overpack). However, to reduce the matrix of experiments to a manageable size, experiments were conducted at 0 and $23-25 \mathrm{~Gy} \mathrm{hr}^{-1}$ only. The required $\gamma$-radiation dose rate was achieved by locating the experiments at appropriate distances from a cobalt-60 source (average energy $1.25 \mathrm{MeV}$ ) in a gamma irradiation facility at Harwell, Oxfordshire, U.K. The dose rate falls in inverse proportion to the square of the distance from the sources. In the work programme, the dose rates received by the cells were measured and calibrated using an ion chamber or Perspex dosimeter. It was also necessary to carry out gas cell experiments and electrochemical measurements in the absence of radiation, to provide control data for comparison with the irradiated experiments. The experiments were carried out at temperatures of $25^{\circ} \mathrm{C}$ and $80^{\circ} \mathrm{C}$. This range of temperatures was chosen to provide data over a range of possible operational conditions and periods after closure of the Belgian repository.

\subsection{Materials}

The carbon steel proposed for use in the Supercontainer is P-235GH (EN 10028-2 steel number 1.0345; BS1501-1:1980) but the nearest grade obtainable in wire form for the experiments described in this paper was Grade 1017, which has the composition (wt\%): C 0.17; Si 0.06; Mn 0.81; P 0.01; S 0.03; Cr 0.038. This steel was used in the form of $0.4 \mathrm{~mm}$ diameter wire; wire was used to provide a high surface area in the gas cell measurements. The total exposed surface area of the wire in the gas cells was $0.1 \mathrm{~m}^{2}$. All of the wires used in the current study were pickled under anoxic conditions in acid and thoroughly washed in demineralised water before use to minimise the amount of residual air-formed oxide. The same type of wire was used for electrodes in the electrochemical measurements.

The cementitious buffer proposed for use in the Belgian Supercontainer concept has the following composition $\left(\mathrm{kg} / \mathrm{m}^{3}\right)$ : CEM I 42.5 N-LA-HSR-LH: 350; Calcitec 2001 MS (ground calcium carbonate): 50; sand 0/4 (limestone): 708; calcareous aggregates (2/6): 414; calcareous aggregates 
(6/14): 191; calcareous aggregates (6/20): 465; w/c ratio 0.50; superplasticiser (Glenium, PC) : 4.4. The corrosion experiments were carried out in a simplified model porewater for this buffer material, corresponding to a relatively short period of time in the repository (known as 'Young cement porewater', $\mathrm{YCW}$ ), with the following composition (mmol/L): $\mathrm{SO}_{4}^{2-} 2.4 ; \mathrm{OH}^{-} 510 ; \mathrm{K}^{+} 370 ; \mathrm{Na}^{+} 140 ; \mathrm{pH} \sim 13.4$. Test solutions for the corrosion experiments were prepared under argon in a glovebox.

\subsection{Measurements of gas generation}

The rate of hydrogen production due to the anaerobic corrosion of steel wires in YCW with and without radiation was measured using a barometric gas cell technique [1]. The test pieces were placed in zirconia crucibles, which were used because of their resistance to chemical and radiochemical degradation in alkaline conditions. Any gas produced in the test cell caused a pressure increase, which resulted in the mercury rising up a glass manometer column. By measuring the height of the mercury it was possible to calculate the volume of gas produced and hence to derive the corrosion rate, based on Equation 2 (i.e. formation of magnetite was assumed). The results were corrected for temperature and external atmospheric pressure fluctuations. It has been estimated that the technique is sensitive to corrosion rate changes of $<0.001 \mu \mathrm{m} \mathrm{yr}^{-1}$ [5]. In order to allow for the possible release of gas due to radiolytic breakdown of the cell materials or radiolysis of the test solution, a control cell was set up for each test environment. The control cells were identical to the test cells, but did not contain any steel wires or in one case any steel or solution.

Carbon steel wire was cut into $79.58 \mathrm{~m}$ lengths (giving a total surface area of $0.1 \mathrm{~m}^{2}$ ), wound into a coil then degreased in acetone. All subsequent cell preparation was conducted in an argon-purged glove box $\left(\mathrm{O}_{2}<10 \mathrm{ppm}\right.$ in the argon; this is equivalent to $<1 \mathrm{ppb}$ oxygen dissolved in the solution, based on Henry's Law), to ensure initial anoxic conditions in the cells. The wire was pickled in an ultrasonic bath containing $10 \% \mathrm{HCl}$ for 5 minutes, in order to remove the residual air-formed oxide, then rinsed for one minute in an ultrasonic bath containing deionised water, further rinsed twice in deionised water, then ethanol, and finally dried overnight before weighing. The deaerated test solutions were prepared inside the glovebox and the cell was assembled by joining the ground glass joints using two-part epoxy resin. The cell bubblers were filled with silicone oil and the manometers were filled with mercury. The cells were sealed by closing the tap between the cell and the bubbler and removed from the glovebox. The manometer tube was then attached.

After assembly, each pair of cells (i.e. one test cell plus one control cell) was maintained at the required test temperature using aluminium heating blocks (irradiated cells) and oil baths (unirradiated cells). The control cells were identical to the test cells but did not contain any wire (one control cell did not contain any wire or solution). They were used to monitor the amount of gas produced by radiolytic degradation of the construction materials and the water, and the values obtained were used to adjust the data obtained from the corrosion test cells. Gas production measurements were made at appropriate intervals to accommodate the expected initial high corrosion rate and the subsequent decrease in rate. Periodically it was necessary to release gas produced in the cells through the bubbler filled with silicone oil, which was normally valved off, so that the mercury level was lowered in the glass manometer column. The matrix of gas cell experiments carried out is shown in Table 1 (in white). All experiments were carried out in duplicate.

\subsection{Electrochemical measurements}

In order to develop a fuller understanding of the electrochemical behaviour of anaerobically corroding steel it was necessary to make electrochemical measurements in representative environments (i.e. anoxic alkaline porewater simulant). The aim of these measurements was to compare the electrochemical behaviour of carbon steel in irradiated and un-irradiated, anoxic alkaline porewater conditions. The 
electrochemical cells were set up containing the following electrodes, which were attached to metal wires (either platinum or Kovar) that passed through the glass-to-metal seals in the lid of the test cells:

- two anaerobically corroding steel test electrodes - approximately $0.4 \mathrm{~mm}$ diameter by $55 \mathrm{~mm}$ long, which were pickled in acid before immersion, under anoxic conditions;

- a gold electrode to measure Eh, redox potential;

- a platinum foil counter electrode, which was also used to monitor Eh;

- an oxidised tungsten wire pseudo-reference electrode, which was prepared by heating to a yellow colour in air.

Table 1. Matrix of gas cell experiments (white) and electrochemical measurements (grey) in 'Young cement water'.

\begin{tabular}{|l|l|l|l|l|}
\hline \multicolumn{1}{|c|}{ Tests in solution } & $\begin{array}{l}\mathbf{C C l}] \\
\left(\mathbf{m g ~ l}^{-\mathbf{1}}\right)\end{array}$ & $\begin{array}{l}\text { Temp } \\
\left({ }^{\circ} \mathbf{C}\right)\end{array}$ & $\begin{array}{l}\gamma \text {-dose rate } \\
\left(\mathbf{G y ~ h r ~}^{-1}\right)\end{array}$ & $\begin{array}{l}\text { Number } \\
\text { of tests }\end{array}$ \\
\hline Young Cement Water + steel & 0 & 25,80 & 0,25 & 8 \\
\hline Young Cement Water only (blank) & 0 & 25,80 & 0,25 & 8 \\
\hline Cells with no water or steel & 0 & 80 & 25 & 2 \\
\hline Young Cement Water + steel & 100 & 80 & 0,25 & 4 \\
\hline Young Cement Water only (blank) & 100 & 80 & 0,25 & 4 \\
\hline Young Cement Water + steel & 0 & 25,80 & 0,25 & 4 \\
\hline Young Cement Water + steel & 100 & 80 & 0,25 & 2 \\
\hline
\end{tabular}

There are only a small number of reference electrodes that are suitable for use in highly alkaline conditions, such as cementitious porewater simulant. In the current work the use of glass reference electrodes for long-term measurements was avoided because under highly alkaline conditions glass is attacked and the silicate that would be released into the test solution could affect the corrosion behaviour of steel. The two reference electrode systems chosen for use in the electrochemical experiments were $\mathrm{Hg} / \mathrm{HgO} / \mathrm{OH}^{-}$and a tungsten-tungsten oxide pseudo-reference electrode. The tungsten-tungsten oxide electrode potentials were calibrated in $\mathrm{YCW}$ under deoxygenated conditions by measuring against a custom-built $\mathrm{Hg} / \mathrm{HgO} / \mathrm{OH}^{-}$reference electrode containing $\mathrm{YCW}$ (this has a reference potential of $+118 \mathrm{mV}$ vs $\mathrm{NHE}$ for a $0.5 \mathrm{M} \mathrm{OH}^{-}$solution). $\mathrm{The} \mathrm{Hg} / \mathrm{HgO} / \mathrm{OH}^{-}$reference electrodes were constructed using miniature zirconia $\left(\mathrm{ZrO}_{2}\right)$ crucibles into which a PTFE sheathed Kovar wire was placed in contact with a mercury bead placed in the bottom of the crucible. A slurry of YCW and mercury oxide was placed on top of the bead of mercury, followed by some YCW solution. A small plug of silicone rubber was used to seal the electrode but with sufficient ionic conduction around the seal to provide contact with the test solution. In some cases a small thread of carbon fibre was used to act as an ionic conductor (i.e. a salt bridge). Each of the irradiated electrochemical cells used an in-situ $\mathrm{Hg} / \mathrm{HgO}$ reference electrode as well as a tungsten pseudo-reference electrode, but the unirradiated cells used a pseudo-reference tungsten reference electrode only. As a result of the calibration using the in situ $\mathrm{Hg} / \mathrm{HgO}$ reference electrode a value for the tungsten pseudo-reference electrode of $600 \mathrm{mV}$ vs SHE in deaerated YCW was applied. The error on this measurement is estimated to be $\pm 100 \mathrm{mV}$, but this does not affect the validity of the corrosion rate measurements made using the LPR, since they were based on the measured $\mathrm{E}_{\text {corr }}$ value taken at the start of the measurement and the potential sweeps were made relative to the measured initial potential.

The test solution for the electrochemical measurements (i.e. YCW) was placed in a zirconia crucible, as for the gas cell measurements, and the cell was assembled in an argon-purged glovebox (oxygen concentration in argon gas $<10 \mathrm{ppm}$ ). The ground glass joint around the lid of the cell was sealed using two-part epoxy resin and then placed either in an oil bath at the desired temperature for unirradiated experiments or in a thermostatically controlled aluminium heater block for the irradiated 
AMP 2010

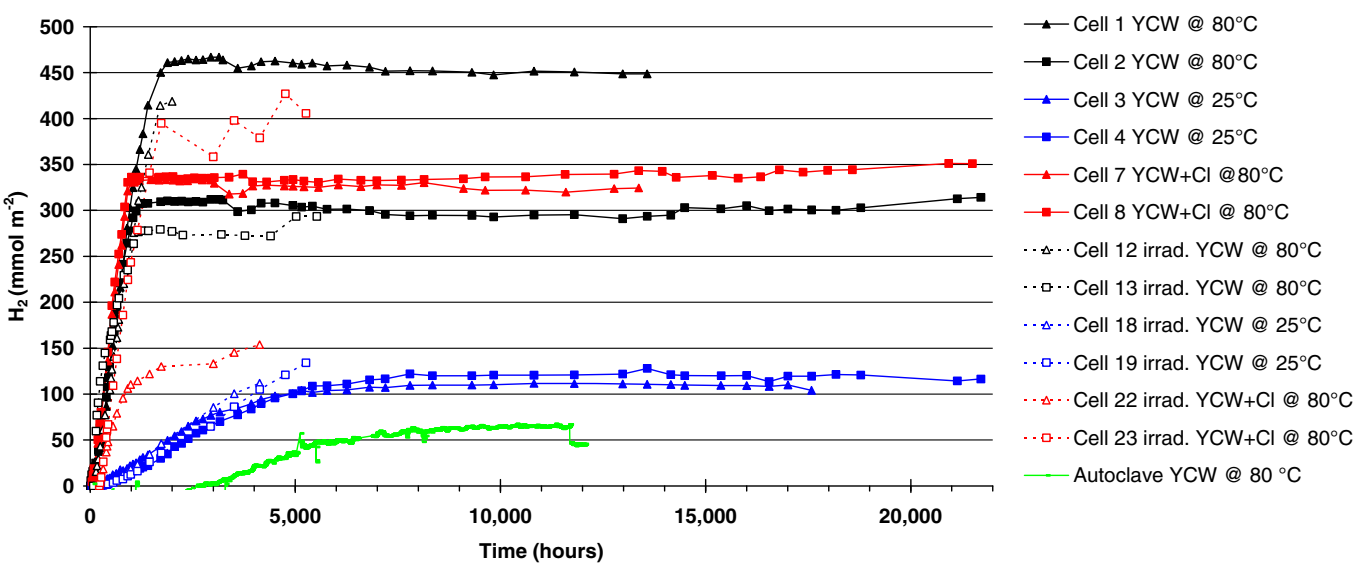

Figure 1. Hydrogen production rate for carbon steel in Young Cement Water simulant, under unirradiated and irradiated conditions $\left(25 \mathrm{~Gy} \mathrm{hr}^{-1}\right)$, as a function of temperature and chloride concentration (adjusted against control cells). Also shown is equivalent unirradiated autoclave experimental data for comparison [2].

experiments. The electrochemical cells were used to monitor the corrosion potential of the carbon steel electrodes, together with their corrosion rates based on linear polarisation resistance measurements. Electrochemical measurements were made using ACM or Solartron equipment. The test conditions for the electrochemical test cells are shown in Table 1 in grey.

\section{RESULTS}

\subsection{Gas generation}

The results from the gas cell measurements, expressed as the cumulative volume of hydrogen produced and the corresponding anaerobic corrosion rates (assuming magnetite), are shown in Figure 1 and Figure 2 respectively. Both these plots show the data corrected using the blank cells (i.e. the gas generation rates have been corrected to allow for gas released due to thermal or radiation effects). Figure 1 also shows data obtained in a separate autoclave experiment to measure gas generation rate [2]. In this experiment it is believed that there was some initial oxygen contamination, which prevented the onset of anaerobic corrosion and hydrogen generation at the start (i.e. there was an incubation period before hydrogen generation started). The fall in pressure after $\sim 12,000$ hours was due to the removal of a gas sample for analysis. For clarity, Figure 2 shows the data for only one of each of the duplicate cells. It should be noted that there were two perturbations to the cells operating at $80^{\circ} \mathrm{C}$ due to a loss of power, these occurred at $\sim 3500$ hours and at $\sim 14000$ hours; this explains why the hydrogen production rate appears to fall below zero during these periods. The results from the gas generation rate experiments follow a similar pattern to that seen in previous investigations of the anaerobic corrosion rate of carbon steel in alkaline conditions, with an initial peak in gas generation, followed by a decline to a low rate. Initially the corrosion rate is greater at $80^{\circ} \mathrm{C}$ than at $25^{\circ} \mathrm{C}$, but at $80^{\circ} \mathrm{C}$ the corrosion rate falls rapidly between 1,000 and 2,000 hours, while the corrosion rate at $25^{\circ} \mathrm{C}$ falls more slowly. There is some scatter in the results, which is more noticeable at $80^{\circ} \mathrm{C}$ than at $25^{\circ} \mathrm{C}$, but occurred in both irradiated and unirradiated conditions. However, within the experimental scatter there is no significant difference in the rate of gas production in cells irradiated at $25 \mathrm{~Gy} \mathrm{hr}^{-1}$ compared to the unirradiated cells.

It should be noted that the experimental duration of the irradiated experiments was shorter than that for the unirradiated experiments, due to degradation of the gas cell valves under irradiation. These tests 


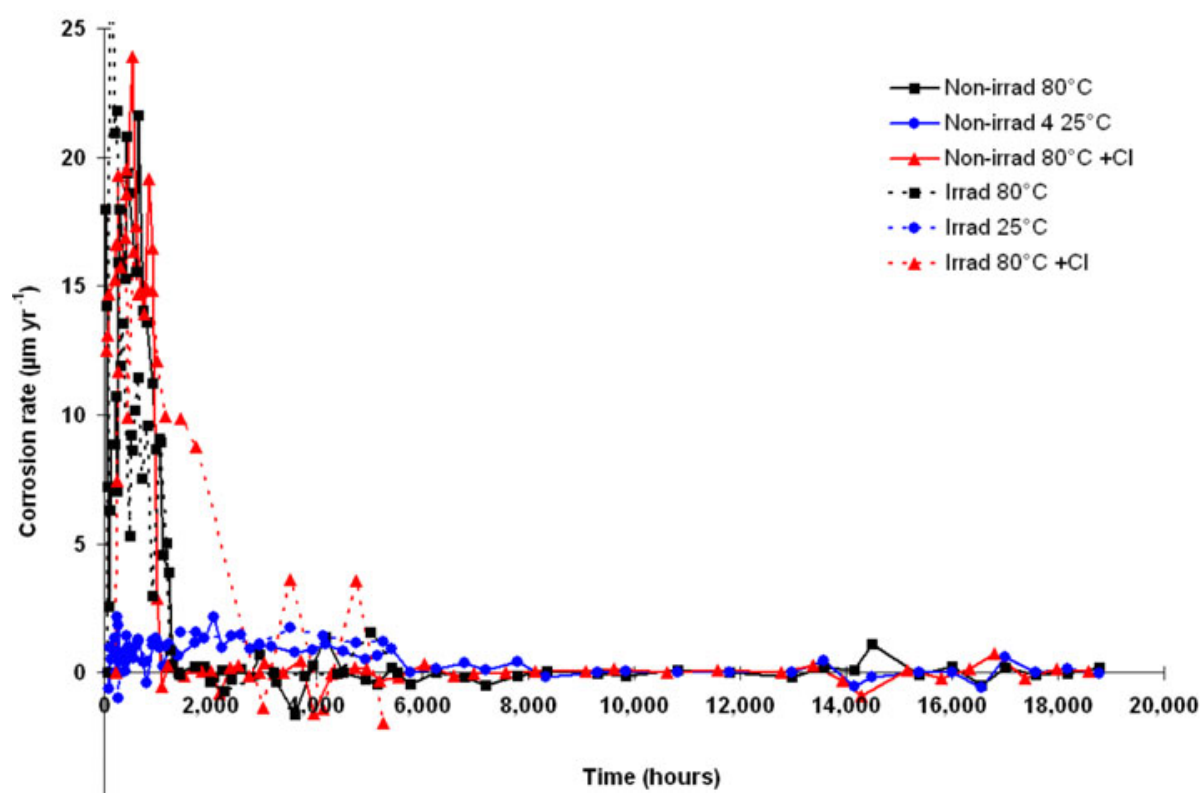

Figure 2. Anaerobic corrosion rate for carbon steel in Young Cement Water simulant, under non-irradiated and irradiated conditions $\left(25 \mathrm{~Gy} \mathrm{hr}^{-1}\right)$, as a function of temperature and chloride concentration (adjusted against control cells).

are currently being repeated. Small additions of chloride (100 ppm) to the test solution do not appear to have an adverse effect on the corrosion rate, in agreement with previous observations [5].

Weight loss measurements were carried out on some of the samples after dismantling and the composition of the corrosion product was analysed using Raman spectroscopy [2]. These measurements demonstrated good agreement between the weight loss measurements and the gas generation measurements. The corrosion product was confirmed as being magnetite by Raman spectroscopy, with a greater crystallinity being observed at the higher temperature (i.e. $80^{\circ} \mathrm{C}$ ).

\subsection{Electrochemical measurements}

Examples of the electrochemical potential measurements for the test electrodes in un-irradiated conditions, measured using the pseudo-reference tungsten electrode, are shown in Figure 3. These data show that the corrosion potential of the steel and the Eh values of the gold and platinum rapidly fell to values close to the hydrogen evolution potential at $\mathrm{pH} 13.6$; assuming a low hydrogen pressure of $1 \mathrm{ppm}$ $\mathrm{H}_{2}$ in argon (i.e. $10^{-6}$ atmospheres $\mathrm{H}_{2}$ ) the equilibrium potential for hydrogen evolution is $-630 \mathrm{mV}$ vs NHE.

It is reasonable to assume this overpressure of hydrogen given the small volume of hydrogen that would be generated in the test cell by anaerobic corrosion of a short length of steel wire. Examples of the potentials measured for electrodes in the irradiated cells are shown in Figure 4 and Figure 5. These potentials were measured directly against an in situ $\mathrm{Hg} / \mathrm{HgO}$ reference electrode and the results were then converted to the NHE scale. It should be noted that there was a time gap of a few days between monitoring the cells in unirradiated conditions and monitoring the potentials under irradiation, during which time the cells were transferred to the irradiation facility and set up. The rapid rise in the potential at $\sim 1600$ hours in Figure 4 and 180 hours in Figure 5 is believed to be due to the ingress of oxygen into the cell, due to failure of the glass-to-metal seals (as shown by leak testing after the test cells were 
AMP 2010

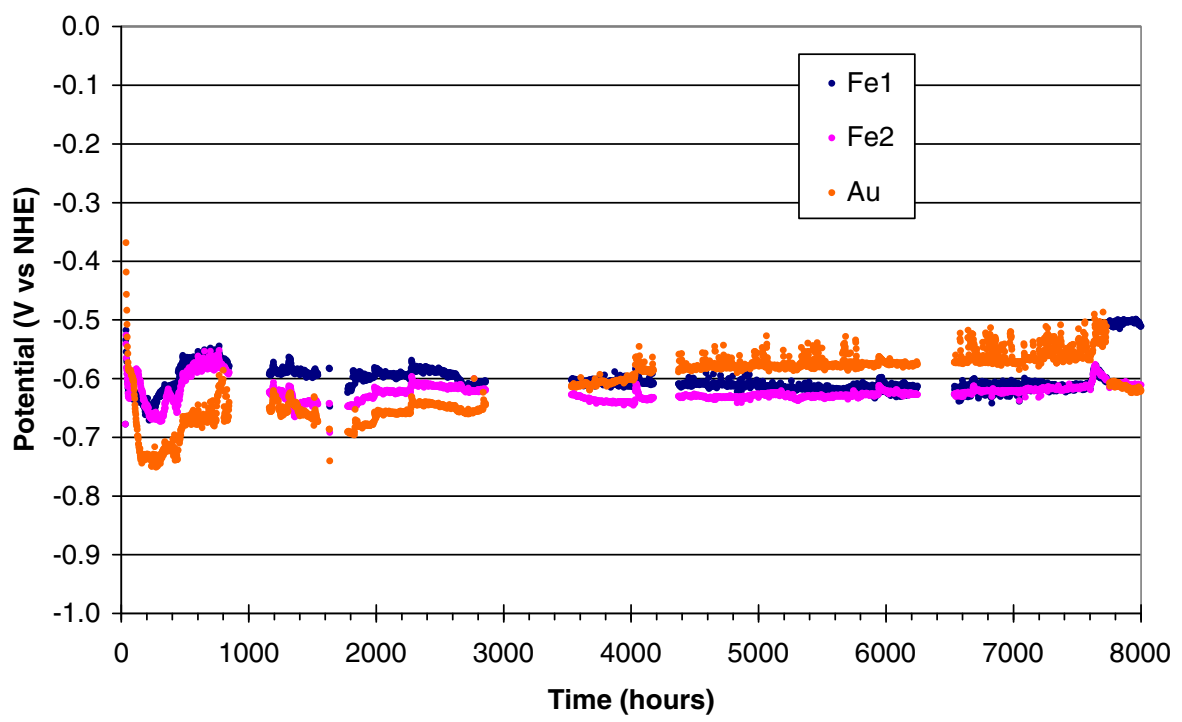

Figure 3. Results of electrochemical potential measurements for carbon steel in $\mathrm{YCW}+0 \mathrm{ppm} \mathrm{Cl}^{-}$, under nonirradiated conditions at $80^{\circ} \mathrm{C}$ : Cell 3 .

removed and examined). The fact that such a large change in potential occurred when oxygen ingress occurred confirms that the starting test conditions were originally anoxic.

In addition, in Figure 5 it is possible to observe small peaks in the potential plots for the tungsten and steel electrodes. These peaks correspond to the radiation sources being taken into and out of the radiation cell to allow man-access for experimental set-up work; an expanded plot is shown in Figure 6. It is possible that the presence of radiation had an effect on the stability of the reference electrode, but the fact that the size of the transients is different for the four electrodes monitored, suggests that there was a genuine small effect on the potential of the steel electrodes and that these potentials became more negative when exposed to radiation. Furthermore, separate trials have since been carried out to establish whether gamma radiation had an effect on reference electrode stability and it has been found that the effects on a range of reference electrode types were negligible.

The corrosion rates measured in the non-irradiated and irradiated cells using the LPR technique are given in Table 2. There is some scatter in these data but they are of the same order of magnitude as those measured using the gas evolution technique (see Figure 2).

\section{DISCUSSION}

The gas generation data obtained in the current study are consistent with previous investigations of the anaerobic corrosion of steel in alkaline conditions [5]. A high initial corrosion rate was observed on pickled surface, which reduced to a far lower long-term rate $\left(<1 \mu \mathrm{m} \mathrm{yr}^{-1}\right.$ and falling). The initial corrosion rate was shown to be higher at $80^{\circ} \mathrm{C}$ than at $25^{\circ} \mathrm{C}$, but reduced more rapidly at $80^{\circ} \mathrm{C}$ than at $25^{\circ} \mathrm{C}$. At $25 \mathrm{~Gy} \mathrm{hr}^{-1}, \gamma$-radiation does not appear to significantly increase the rate of gas production. This is consistent with previous work at lower $\mathrm{pH}$ [6] where a sustained effect was only observed at a higher dose rate $\left(300 \mathrm{~Gy} \mathrm{hr}^{-1}\right)$.

The potentials of the steel electrodes passed through a minimum after a few hundred hours (e.g. Figure 3) and this corresponds to the time of the maximum corrosion rate in the gas generation experiments. It is noticeable that the potential of the steel electrodes in the irradiated experiments also fell to more negative values after exposure to irradiation; this may have been due to the continued 
EPJ Web of Conferences

Table 2. Results of corrosion rate measurements using the LPR method $\left(\mu \mathrm{m} \mathrm{yr}^{-1}\right)$.

\begin{tabular}{|l|c|c|c|c|c|c|}
\hline & Cell 1 & Cell 2 & Cell 3 & Cell 4 & Cell 5 & Cell 6 \\
\hline Temperature & 80 & 25 & 80 & 25 & 80 & 80 \\
\hline Chloride (ppm) & 100 & 0 & 0 & 0 & 0 & 100 \\
\hline Dose rate $\left(\mathrm{Gy} \mathrm{hr}{ }^{-1}\right)$ & 0 & 0 & 0 & 25 & 25 & 25 \\
\hline Time (hrs) & & & & & & \\
\hline 860 & 5.8 & & 1.8 & & & \\
\hline 1130 & 3.8 & 2.5 & 4.5 & & & \\
\hline 1370 & 4.5 & 2.9 & 3.6 & & & \\
\hline 3500 & 7 & 5.8 & 4.7 & & & \\
\hline 6550 & 2.7 & 8.1 & 3 & & & \\
\hline 50 & & & & 4.5 & & \\
\hline 150 & & & & 9.2 & 0.65 & \\
\hline 410 & & & & 6.3 & & 0.025 \\
\hline 630 & & & & 3 & & \\
\hline 1160 & & & & 3.8 & & \\
\hline
\end{tabular}

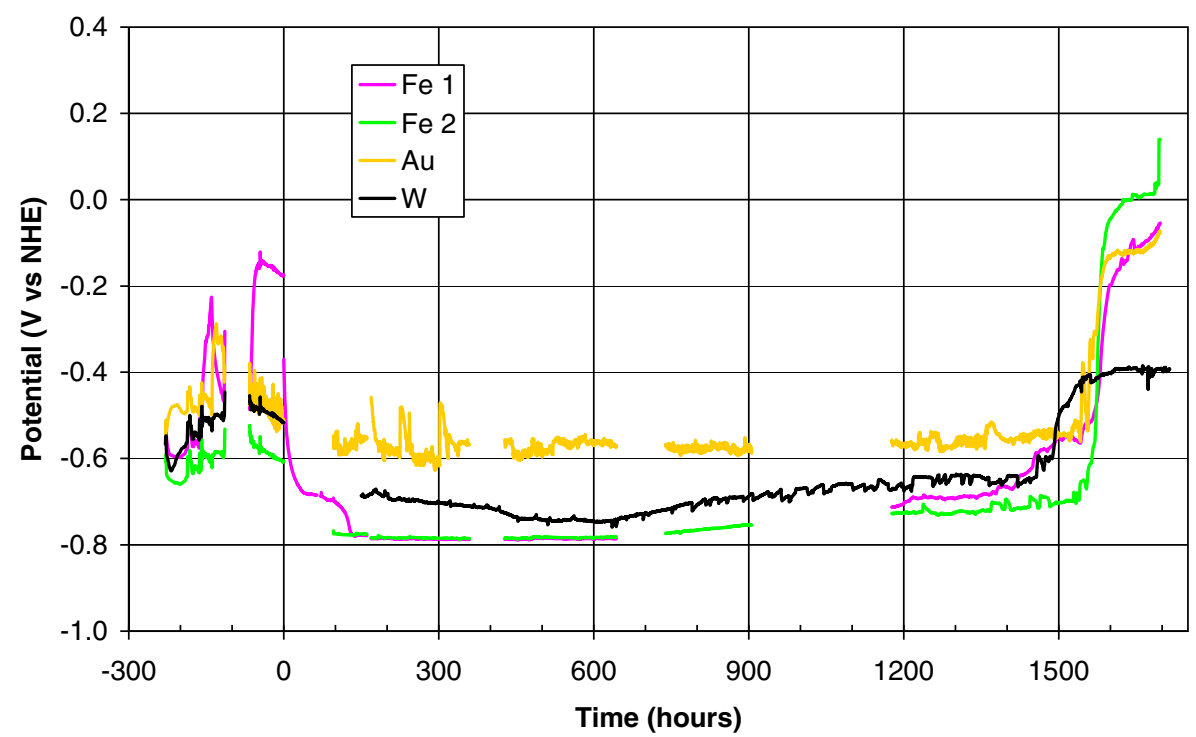

Figure 4. Results of electrochemical potential measurements for carbon steel in YCW, under irradiated conditions $\left(25 \mathrm{~Gy} \mathrm{hr}^{-1}\right)$ at $25^{\circ} \mathrm{C}, 0 \mathrm{ppm} \mathrm{Cl}{ }^{-}$: Cell 4 . Time of 0 hours corresponds to the start of the irradiation period. There was a time gap of a few days between the measurements under nonirradiated conditions and the start of the irradiation. Oxygen ingress occurred at $\sim 1600$ hours.

decrease in the rate of corrosion, but it may also have had a contribution from the effects of radiolysis in the test solution. Figure 6 shows that radiation tended to depress the rest potential of the steel electrodes, but the exact reasons for this effect have not yet been established and radiochemical modelling would be required to further understand its mechanism.

The electrochemical corrosion rate measurements typically yielded values that were broadly consistent with the gas generation rate results and those calculated from weight loss. Any effect 
AMP 2010

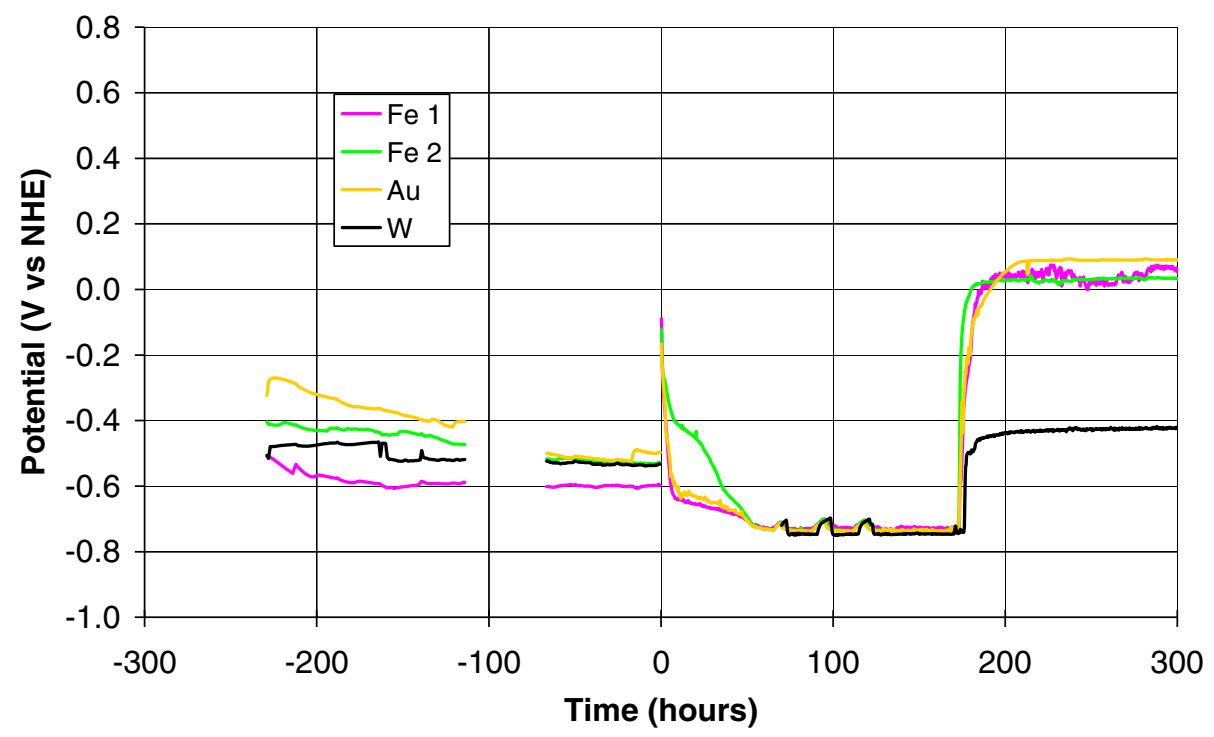

Figure 5. Results of electrochemical potential measurements for carbon steel in YCW, under irradiated conditions $\left(25 \mathrm{~Gy} \mathrm{hr}^{-1}\right)$ at $80^{\circ} \mathrm{C}, 0 \mathrm{ppm} \mathrm{Cl}^{-}$. . Cell 5 . Time of 0 hours corresponds to the start of the irradiation period. There was a time gap of a few days between the measurements under non-irradiated conditions and the start of the irradiation. Oxygen ingress occurred at $\sim 180$ hours.

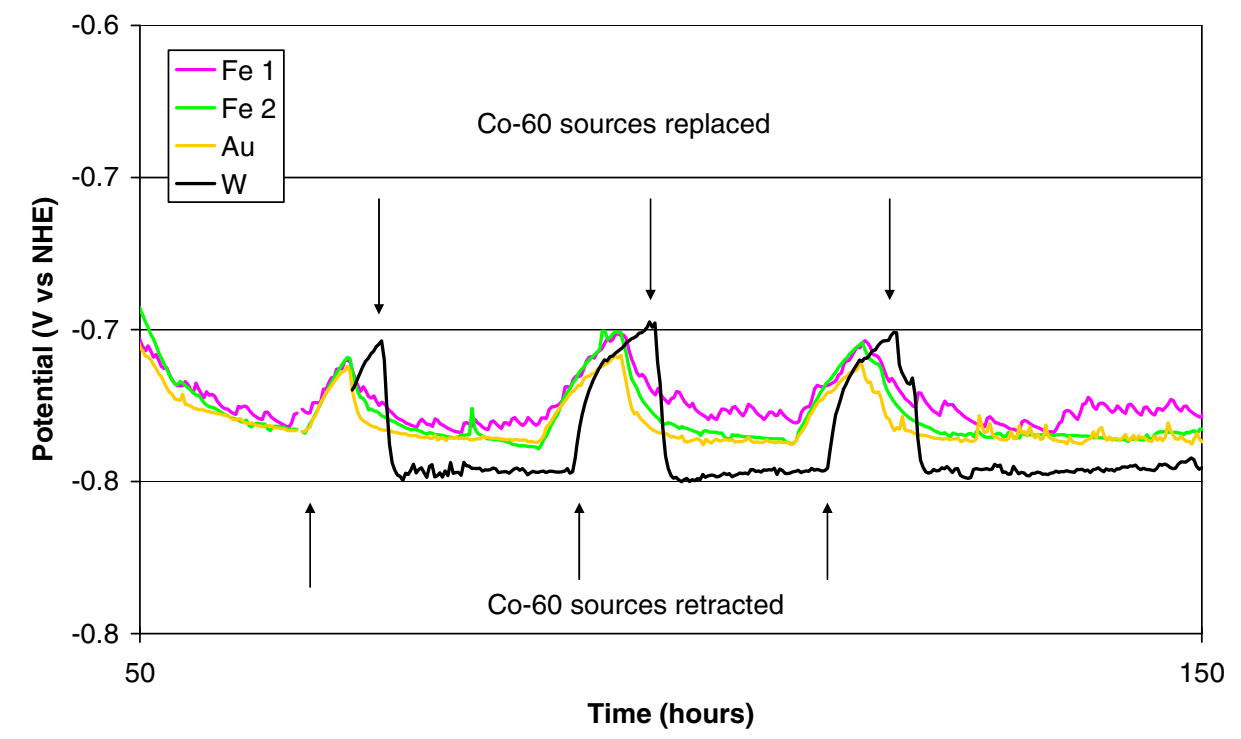

Figure 6. Results of electrochemical potential measurements for carbon steel in YCW, under irradiated conditions $\left(25 \mathrm{~Gy} \mathrm{hr}^{-1}\right)$ at $80^{\circ} \mathrm{C}, 0 \mathrm{ppm} \mathrm{Cl}^{-} .:$Cell 5 - expanded scale showing effect of source removal on potentials.

of radiation on the anaerobic corrosion rate at a dose rate of $25 \mathrm{~Gy} \mathrm{hr}^{-1}$ appears to be small and may be within the inherent experimental scatter. Further experiments are in progress to confirm this conclusion. 
EPJ Web of Conferences

\section{CONCLUSIONS}

1. The corrosion rate for carbon steel in anoxic cementitious porewater simulant relevant to the Belgian Supercontainer concept has been measured using gas generation, weight loss and electrochemical methods and good agreement has been found between them. Any effect of radiation on the anaerobic corrosion rate at a dose rate of $25 \mathrm{~Gy} \mathrm{hr}^{-1}$ appears to be small.

2. Electrochemical measurements have shown that the corrosion potential of steel is close to the expected hydrogen evolution potential. Radiation dose rates of $25 \mathrm{~Gy} \mathrm{hr}^{-1}$ can cause negative potential fluctuations of $\sim 100 \mathrm{mV}$. The potential shift caused by irradiation does not appear to be sufficient to cause a significant change in corrosion rate, but this will be confirmed by ongoing measurements.

The authors would like to thank NIRAS-ONDRAF, Belgium, for financial support.

\section{References}

[1] N.R. Smart, A.P. Rance, R.J. Winsley, P.A.H. Fennell, B. Reddy, B. Kursten, The Effect of Irradiation on the Corrosion of Carbon Steel in Alkaline Media, presented at the NUCPERF conference on Long-Term Performance of Cementitious Barriers and Reinforced Concrete in Nuclear power plants and Waste Management, Cadarache, France, 30 March-2 April, (2009)

[2] R.J. Winsley, N.R. Smart, A.P. Rance, P.A.H. Fennell, B. Reddy, B. Kursten, Further Studies on the Effect of Irradiation on the Corrosion of Carbon Steel in Alkaline Media, presented at the 4th International Workshop on Long-Term Prediction of Corrosion Damage in Nuclear Waste Systems, Bruges, June 2010

[3] N.R. Smart, D.J. Blackwood, L. Werme, Corrosion 58, 547 (2002)

[4] N.R. Smart, D.J. Blackwood, L. Werme, Corrosion 58, 627 (2002)

[5] N.R. Smart, D.J. Blackwood, G.P. Marsh, C.C. Naish, T.M. O’Brien, A.P. Rance and M.I. Thomas, The Anaerobic Corrosion of Carbon and Stainless Steels in Simulated Cementitious Repository Environments: A Summary Review of Nirex Research, AEAT/ERRA-0313, 2004 (available from U.K. Nuclear Decommissioning Authority)

[6] N.R. Smart, A.P. Rance and L.O. Werme, J. Nuc. Mat. 379, 97 (2008)

[7] G. Schikorr, Z. Anorg. Chem 212, 33 (1933) 